\title{
Desulfotomaculum alcoholivorax sp. nov., a moderately thermophilic, spore-forming, sulfate-reducer isolated from a fluidized-bed reactor treating acidic metal- and sulfate-containing wastewater
}

Correspondence

Anna H. Kaksonen anna.kaksonen@tut.fi

\author{
Anna H. Kaksonen, ${ }^{1}$ Stefan Spring, ${ }^{2}$ Peter Schumann, ${ }^{2}$ \\ Reiner M. Kroppenstedt ${ }^{2}$ and Jaakko A. Puhakka ${ }^{1}$ \\ ${ }^{1}$ Institute of Environmental Engineering and Biotechnology, Tampere University of Technology, \\ Tampere, Finland \\ ${ }^{2} \mathrm{DSMZ}$ - German Collection of Microorganisms and Cell Cultures, Braunschweig, Germany
}

The genus Desulfotomaculum constitutes a group of rodshaped, endospore-forming, sulfate-reducing bacteria. The genus currently includes mesophilic, moderately thermophilic and thermophilic species (Werkman \& Weaver, 1927; Campbell \& Postgate, 1965; Vandieken et al., 2006). The previously described mesophilic (optimal temperature $25-40{ }^{\circ} \mathrm{C}$ ) Desulfotomaculum species are D. ruminis (Campbell \& Postgate, 1965), D. acetoxidans (Widdel \& Pfennig, 1977), D. sapomandens (Cord-Ruwisch \& Garcia, 1985), D. aeronauticum (Hagenauer et al., 1997), D. halophilum (Tardy-Jacquenod et al., 1998) and D. gibsoniae (Kuever et al., 1999). The thermophilic (optimal temperature $50-70{ }^{\circ} \mathrm{C}$ ) species are D. alkaliphilum (Pikuta et al., 2000), D. australicum (Love et al., 1993), D. carboxydivorans (Parshina et al., 2005), D. geothermicum (Daumas et al., 1988), D. kuznetsovii (Nazina et al., 1989), D. luciae

Abbreviation: FBR, fluidized-bed reactor.

The GenBank/EMBL/DDBJ accession number for the 16S rRNA gene sequence of strain RE35E $1^{\top}$ is AY548778.
(Liu et al., 1997), D. nigrificans (Werkman \& Weaver, 1927; Campbell \& Postgate, 1965), D. putei (Liu et al., 1997), D. solfataricum (Goorissen et al., 2003), D. thermoacetoxidans (Min \& Zinder, 1990), D. thermobenzoicum with two subspecies, namely subsp. thermobenzoicum and subsp. thermosyntrophicum (Tasaki et al., 1991; Plugge et al., 2002), D. thermocisternum (Nilsen et al., 1996), D. thermosapovorans (Fardeau et al., 1995) and D. thermosubterraneum (Kaksonen et al., 2006b). Additionally, the reclassification of 'Desulfotomaculum nigrificans subsp. salinus' as a novel species ('Desulfotomaculum salinum') has been proposed (Nazina et al., 2005). Currently, Desulfotomaculum arcticum is the only sulfate-reducing member of the genus that has an optimal temperature above $40{ }^{\circ} \mathrm{C}$ and below $50{ }^{\circ} \mathrm{C}$ (Vandieken et al., 2006). Recently, we reported the isolation of sulfate-reducers from fluidized-bed reactors (FBRs) treating acidic metal- and sulfate-containing wastewater (Kaksonen et al., 2004c). This paper describes one of those isolates, strain RE35E ${ }^{\mathrm{T}}$, a novel, moderately thermophilic, spore-forming, sulfatereducing bacterium. 
Strain RE35E1 $1^{\mathrm{T}}$ was isolated from a sulfidogenic laboratory-scale FBR after continuous-flow operation at $35{ }^{\circ} \mathrm{C}$ for more than 600 days (Kaksonen et al., 2004c). The FBR had been inoculated with enrichment cultures originating from methanogenic granular sludge (Neson Oy, Jokioinen, Finland) and sediments from Outokumpu's Pyhäsalmi mine, Finland (Kaksonen et al., 2003b). The performance and microbiology of the FBR have been described previously (Kaksonen et al., 2003a, b, 2004a, b, c). For comparison, Desulfotomaculum arcticum DSM $17038^{\mathrm{T}}$, obtained from the Deutsche Sammlung von Mikroorganismen und Zellkulturen (DSMZ, Braunschweig, Germany), was used as a reference strain.

The isolation of strain RE35E1 $1^{\mathrm{T}}$ was performed at $35{ }^{\circ} \mathrm{C}$ using ethanol-containing modified Postgate growth medium (pH 7.0-7.5) (Kaksonen et al., 2004c) and anaerobic roll tubes solidified with $1.5 \%$ agar. For DNA isolation and chemotaxonomic analyses (including whole-cell fatty acid determinations), the strain was cultured at $35{ }^{\circ} \mathrm{C}$ in modified DSM medium 641 containing pyruvate as an electron donor. The medium was supplemented with selenate/tungstate solution (DSM medium 385) at $1 \mathrm{ml} \mathrm{l}^{-1}$; sodium dithionite $\left(25 \mathrm{mg} \mathrm{l}^{-1}\right)$ was used as the reducing agent instead of $\mathrm{Na}_{2} \mathrm{~S}$.

The isolate was examined using phase-contrast microscopy (Axioskop 2; Zeiss) and photomicrographs were obtained using the agar slide technique as described previously (Kaksonen et al., 2004c). Cells were examined for flagella by using staining as described by Heimbrook et al. (1989) followed by light microscopy (Axiophot; Zeiss). Spore formation by the strain was determined microscopically and by testing for growth after heat treatment $\left(80{ }^{\circ} \mathrm{C}\right.$ for $20 \mathrm{~min}$ ). The Gram type of the cells was determined using both Gram staining and the $\mathrm{KOH}$ test (Gregersen, 1978).

The effects of temperature, $\mathrm{pH}$ and $\mathrm{NaCl}$ concentration on growth were determined as described previously (Kaksonen et al., 2006a). The ability of the strain to utilize various electron donors (at $1-20 \mathrm{mM}$ ) was tested in a medium containing $20 \mathrm{mM}$ sulfate (as $\mathrm{Na}_{2} \mathrm{SO}_{4}$ ). The medium was as the modified 641 medium described above, except that Na-thiosulfate and yeast extract were omitted and $\mathrm{MgSO}_{4}$ was replaced with $\mathrm{MgCl} \cdot 6 \mathrm{H}_{2} \mathrm{O}\left(1 \mathrm{~g} \mathrm{l}^{-1}\right)$. The utilization of various electron acceptors (at $10 \mathrm{mM}$, and for sulfite also at $1 \mathrm{mM})$ was studied using ethanol $(10 \mathrm{mM})$ as the electron donor. Amorphous Fe(III) oxyhydroxide was formed by neutralizing a $\mathrm{FeCl}_{3}$ solution to $\mathrm{pH} 7$ with $\mathrm{NaOH}$. The cultures were incubated for 1-2 weeks. Electron-donor utilization was determined as bacterial growth $\left(\mathrm{OD}_{660}\right.$ in a Shimadzu UV-1601 spectrophotometer or an Ultrospec II LKB Biochrom 4050 UV/visible spectrophotometer), hydrogen sulfide production or substrate conversion. Hydrogen sulfide production was determined spectrophotometrically and substrate conversion was determined by GC as described previously (Kaksonen et al., 2004c). Ferrous iron was determined colorimetrically (UV-1601; Shimadzu) with ferrozine
(Lovley \& Phillips, 1986). Sulfate, sulfite, thiosulfate, nitrate and nitrite concentrations were determined by ion chromatography (DX-120; Dionex).

Diaminopimelic acid isomers were detected in cell-wall hydrolysates by TLC as described previously (Rhuland et al., 1955; Kaksonen et al., 2006b). Respiratory isoprenoid quinones were extracted and analysed according to the methods described by Collins \& Jones (1981), Monciardini et al. (2003) and Groth et al. (1996) by using HPLC and electron impact mass spectrometry (Kaksonen et al., 2006b). Fatty acid methyl esters of cellular fatty acids were obtained by saponification, methylation, extraction and base wash, as described previously (Kämpfer \& Kroppenstedt, 1996; Kroppenstedt, 1985; Miller, 1982). The fatty acid methyl mixtures were separated in a gas chromatograph (5890 Series II; Hewlett Packard) as described previously (Kaksonen et al., 2006b) and analysed using the Microbial Identification Standard software package, Sherlock (version 4.5) (Sasser, 1990).

The methods for the amplification and sequencing of the $16 \mathrm{~S}$ rRNA gene were as described previously (Kaksonen et al., 2004c). The DNA sequence chromatograms were analysed and single primer sequences were compiled using the BioEdit sequence-alignment editor (http://www.ctu. edu.vn/ dvxe/Bioinformatic/Software/BioEdit.htm). Phylogenetic affiliations of the sequences were estimated initially using the program BLAST (http://www.ncbi.nlm. nih.gov/blast/) (Altschul et al., 1990). A phylogenetic tree of the 16S rRNA gene sequence of strain RE35E $1^{\mathrm{T}}$ and related species was constructed using distance matrix and neighbour-joining methods in ARB. No correction factor was used for creating the tree. The robustness of the phylogeny was tested by bootstrap analysis with 1000 iterations. Genomic DNA for $\mathrm{G}+\mathrm{C}$ content (mol\%) determination was released by rupturing cells using a French pressure cell (Thermo Spectronic) and purified by chromatography on hydroxyapatite (Cashion et al., 1977). The DNA was hydrolysed with P1 nuclease and the nucleotides were dephosphorylated with bovine alkaline phosphatase (Mesbah et al., 1989). The G+C content $(\mathrm{mol} \%)$ of the resulting deoxyribonucleosides was

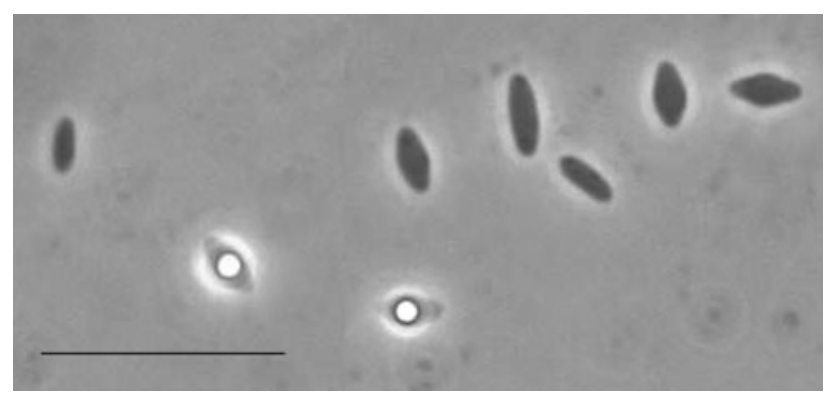

Fig. 1. Phase-contrast micrograph of strain $R E 35 E 1^{\top}$. Bar, $10 \mu \mathrm{m}$. 
determined by using reversed-phase HPLC (Shimadzu) and was calculated from the ratio of deoxyguanosine and thymidine (Tamaoka \& Komagata, 1984; Mesbah et al., 1989).
The cells of strain RE35E $1^{\mathrm{T}}$ were straight rods $0.8-1.0 \mu \mathrm{m}$ in diameter and $2-8 \mu \mathrm{m}$ in length (Fig. 1). The strain formed spherical spores that were able to germinate after a heat shock. The spores were located centrally. The cells

\section{Table 1. Characteristics of strain RE35E $1^{\top}$ compared with those of its closest relatives}

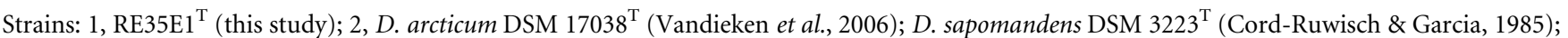
4, D. thermosapovorans DSM $6562^{\mathrm{T}}$ (Fardeau et al., 1995); 5, D. gibsoniae DSM 7213 ${ }^{\mathrm{T}}$ (Kuever et al., 1999); 6, D. geothermicum DSM 3669 (Daumas et al., 1988). All of the organisms shared the following characteristics: spore formation, spherical central or subterminal spores, sulfate $(10 \mathrm{mM})$ reduction and oxidation of formate $(10 \mathrm{mM})$, butyrate $(10 \mathrm{mM})$, hexanoate $(2 \mathrm{mM})$ and ethanol $(10 \mathrm{mM})$ as electron donors. RE35E ${ }^{\mathrm{T}}$ utilized pentanoate, pyruvate, crotonate, propanol and butanol (each at $10 \mathrm{mM}$ ), pentanol, 3-methylbutyrate and 4-methylbutyrate (each at $5 \mathrm{mM})$, phenylacetate $(3 \mathrm{mM})$, octanoate $(2 \mathrm{mM})$ and nonanoate $(0.5 \mathrm{mM})$ as electron donors. RE35E $1^{\mathrm{T}}$ did not utilize nitrate or nitrite (each at $10 \mathrm{mM})$ as an electron acceptor; it did not utilize tartrate $(10 \mathrm{mM})$, citrate, malonate, ribose, arabinose, xylose, glucose, mannose, galactose, myoinositol, sucrose, lactose, maltose, cellobiose, trehalose or glutamate (each at $10 \mathrm{mM}$ ), or glycine or alanine (each at $5 \mathrm{mM}$ ) as electron donors. The concentrations apply only to this study. +, Positive; -, negative; NR, not reported.

\begin{tabular}{|c|c|c|c|c|c|c|}
\hline Characteristic & 1 & 2 & 3 & 4 & 5 & 6 \\
\hline Gram stain & + & - & - & NR & - & - \\
\hline Motility & + & - & + & + & + & + \\
\hline Optimal temperature $\left({ }^{\circ} \mathrm{C}\right)$ & $44-46$ & 44 & 38 & 50 & $35-37$ & 54 \\
\hline $\mathrm{pH}$ range & $6.0-7.5$ & $6.8-7.5$ & $6.3-8.5$ & NR & $6-8$ & $6.0-8.0$ \\
\hline Optimal pH & $6.4-7.3$ & $7.1-7.5$ & 7.0 & $7.2-7.5$ & $6.9-7.2$ & $7.2-7.4$ \\
\hline Optimal salinity $(\mathrm{NaCl}, \%)$ & 0 & $1-1.5$ & NR & 1.5 & NR & $2.4-3.4$ \\
\hline DNA G $+C$ content $(\mathrm{mol} \%)$ & 48 & 48.9 & 48 & 51.2 & 54.8 & 50.4 \\
\hline \multicolumn{7}{|l|}{ Electron acceptors } \\
\hline Sulfite $(10$ or $1 \mathrm{mM})$ & $-1+{ }^{*}$ & + & + & + & + & + \\
\hline Thiosulfate (10 mM) & + & + & + & + & + & NR \\
\hline Sulfur $(10 \mathrm{mM})$ & + & - & + & - & - & - \\
\hline Propionate (10 mM) & - & + & - & - & + & + \\
\hline Heptanoate $(10 \mathrm{mM})$ & + & $+\dagger$ & + & + & NR & - \\
\hline Decanoate $(1 \mathrm{mM})$ & - & $+\dagger$ & + & NR & + & - \\
\hline Dodecanoate $(1 \mathrm{mM})$ & - & $-\dagger$ & + & + & NR & NR \\
\hline Tetradecanoate $(1 \mathrm{mM})$ & + & $+\dagger$ & + & NR & - & NR \\
\hline Hexadecanoate $(1 \mathrm{mM})$ & + & $+\dagger$ & + & + & - & + \\
\hline Isobutyrate $(10 \mathrm{mM})$ & + & $+\dagger$ & NR & - & + & NR \\
\hline 2-Methylbutyrate (10 mM) & + & $+\dagger$ & - & NR & + & NR \\
\hline Benzoate $(5 \mathrm{mM})$ & - & $-\dagger$ & + & - & + & - \\
\hline 4-Hydroxybenzoate (2 mM) & - & $-\dagger$ & + & NR & + & NR \\
\hline Lactate $(20 \mathrm{mM})$ & - & + & - & + & - & + \\
\hline Lactate $(20 \mathrm{mM})$ & - & - & NR & + & NR & NR \\
\hline
\end{tabular}

*Slight production of $\mathrm{H}_{2} \mathrm{~S}$ was observed with $1 \mathrm{mM}$ sulfite, but not with $10 \mathrm{mM}$.

$\dagger$ Determined in this study. 
were motile, having two or more flagella, and were Gram-positive (as determined from both Gram staining and the $\mathrm{KOH}$ test). The temperature, $\mathrm{pH}$ and $\mathrm{NaCl}(\%)$ ranges for growth of strain $\mathrm{RE} 35 \mathrm{E} 1^{\mathrm{T}}$ are as shown in Table 1. Strain $\mathrm{RE}_{5} 5 \mathrm{E} 1^{\mathrm{T}}$ was able to use the following electron acceptors: sulfate, thiosulfate and elemental sulfur (each at $10 \mathrm{mM}$ ) and $1 \mathrm{mM}$ (but not $10 \mathrm{mM}$ ) sulfite. $\mathrm{RE} 35 \mathrm{El}^{\mathrm{T}}$ utilized various alcohols and carboxylic acids or their sodium salts, but not lactate, for example, as electron donors (Table 1). The strain fermented pyruvate.

The cell wall of strain RE35E1 ${ }^{\mathrm{T}}$ contained meso-diaminopimelic acid and the major respiratory isoprenoid quinone was menaquinone MK-7. The whole-cell fatty acid content of strain $\mathrm{RE} 3 \mathrm{E} 1^{\mathrm{T}}$ is listed in Table 2. Significant proportions of iso-branched saturated fatty acids were found, the major fatty acids being iso- $\mathrm{C}_{15: 0}$, iso- $\mathrm{C}_{17: 1} \omega 10 c$ and iso- $\mathrm{C}_{17: 0}$ (Table 2). The $\mathrm{G}+\mathrm{C}$ content of the total DNA of strain RE35E1 ${ }^{\mathrm{T}}$ was $48 \mathrm{~mol} \%$ (Table 1 ). Strain $\mathrm{RE} 35 \mathrm{E} 1^{\mathrm{T}}$ was found to be related to representatives of the genera Desulfotomaculum and Sporotomaculum (Fig. 2), the closest relatives within these genera being $D$. arcticum DSM $17038^{\mathrm{T}}$ (96.3\% 16S rRNA gene sequence similarity) and Sporotomaculum hydroxybenzoicum DSM $5475^{\mathrm{T}}(92.0 \%$ similarity). The $16 \mathrm{~S}$ rRNA gene of $\mathrm{RE} 35 \mathrm{E}^{\mathrm{T}}$ does not contain any long insertions that do not appear in the genes of the closest relatives.

Strain RE35E1 $1^{\mathrm{T}}$ clustered phylogenetically with members of the genera Desulfotomaculum and Sporotomaculum. The strain also exhibits many features typical of these two genera, such as rod-shaped, Gram-positive, spore-forming cells and the presence of MK-7 as the major menaquinone. Strain RE35E1 ${ }^{\mathrm{T}}$ and the members of the genus Desulfotomaculum are able to perform dissimilatory sulfate reduction, unlike the members of the genus Sporotomaculum. RE35E1 $1^{\mathrm{T}}$ differs from its closest relative, D. arcticum DSM $17038^{\mathrm{T}}$, in being able to reduce $S^{0}$ and unable to oxidize propionate, decanoate, lactate, malate, fumarate, succinate or methanol. Moreover, $10 \mathrm{mM}$ sulfite was not reduced by $\mathrm{RE} 35 \mathrm{E} 1^{\mathrm{T}}$. On the basis of the phenotypic and genomic differences described here, strain $\mathrm{RE} 35 \mathrm{E} 1^{\mathrm{T}}$ can be assigned to a novel species of the genus Desulfotomaculum, for which the name Desulfotomaculum alcoholivorax sp. nov. is proposed.

\section{Description of Desulfotomaculum alcoholivorax sp. nov.}

Desulfotomaculum alcoholivorax (al.co.ho.li.vo' rax. N.L. n. alcohol alcohol; L. adj. vorax voracious; N.L. neut. adj. alcoholivorax alcohol-devouring).

Cells are motile, Gram-positive, spore-forming rods (0.8$1.0 \times 2-8 \mu \mathrm{m}$ ). Growth occurs at $33-51{ }^{\circ} \mathrm{C}$ (optimum $44-$ $46{ }^{\circ} \mathrm{C}$ ), $\mathrm{pH} 6.0-7.5$ (optimum $\mathrm{pH} 6.4-7.3$ ) and $\mathrm{NaCl}$ concentrations of $0-0.25 \%$ (optimum $0 \%$ ). Sulfate, thiosulfate, elemental sulfur and sulfite are used as electron acceptors. Alcohols and carboxylic acids (Table 1) are used
Table 2. Whole-cell fatty acid content of strain RE35E $1^{\top}$ in comparison with some reference strains

Strains: 1, RE35E1 ${ }^{\mathrm{T}}$ (this study); 2, D. arcticum DSM $17038^{\mathrm{T}}$ (this study); 3, D. sapomandens DSM $3223^{\mathrm{T}} ; 4$, D. thermosapovorans DSM $6562^{\mathrm{T}} ; 5$, D. gibsoniae DSM $7213^{\mathrm{T}} ; 6$, D. geothermicum DSM $3669^{\mathrm{T}}$ (Kuever et al., 1999). ECL, Equivalent chain-length; DMA, dimethyl acetal; c, cyclopropane; ND, not detected.

\begin{tabular}{|c|c|c|c|c|c|c|c|}
\hline \multirow[t]{2}{*}{ ECL } & \multirow[t]{2}{*}{ Fatty acid } & \multicolumn{6}{|c|}{ Content $(\%)$ in strains: } \\
\hline & & 1 & 2 & 3 & 4 & 5 & 6 \\
\hline 11 & $\mathrm{C}_{11: 0}$ & ND & ND & ND & 0.5 & 1.9 & 0.9 \\
\hline 13.62 & iso- $\mathrm{C}_{14: 0}$ & ND & ND & ND & 1.4 & 1.6 & ND \\
\hline 14 & $\mathrm{C}_{14: 0}$ & 1.3 & 1.0 & 1.0 & 2.1 & 2.6 & 7.9 \\
\hline 14.41 & iso- $\mathrm{C}_{15: 1}$ & ND & 3.9 & 0.5 & 1.0 & $\mathrm{ND}$ & 6.5 \\
\hline 14.48 & $\mathrm{C}_{14: 0} \mathrm{DMA}$ & 0.1 & $\mathrm{ND}$ & $\mathrm{ND}$ & ND & ND & ND \\
\hline 14.63 & iso- $\mathrm{C}_{15: 0}$ & 40.0 & 37.5 & 2.0 & 23.1 & 5.4 & 32.8 \\
\hline 14.71 & anteiso- $\mathrm{C}_{15: 0}$ & 0.4 & 0.4 & ND & ND & ND & 1.4 \\
\hline 14.79 & $\mathrm{C}_{15: 1} \omega 8 c$ & 0.3 & ND & 0.6 & ND & 2.7 & $\mathrm{ND}$ \\
\hline 14.95 & $\mathrm{C}_{16: 0}$ aldehyde & $\mathrm{ND}$ & ND & $\mathrm{ND}$ & 0.6 & 2.2 & $\mathrm{ND}$ \\
\hline 15 & $\mathrm{C}_{15: 0}$ & 1.3 & 0.6 & 0.8 & 1.4 & ND & 1.5 \\
\hline 15.11 & iso- $\mathrm{C}_{15: 0}$ DMA & 0.7 & 0.7 & $\mathrm{ND}$ & 1.2 & ND & 2.2 \\
\hline 15.48 & $\mathrm{C}_{15: 0} \mathrm{DMA}$ & ND & ND & 5.4 & ND & 1.7 & ND \\
\hline 15.63 & iso- $\mathrm{C}_{16: 0}$ & 0.7 & 1.1 & 3.5 & 2.6 & $\mathrm{ND}$ & 1.6 \\
\hline 15.77 & $\mathrm{C}_{16: 1} \omega 9 c$ & ND & $\mathrm{ND}$ & 6.5 & 0.7 & 3.3 & ND \\
\hline 15.82 & $\mathrm{C}_{16: 1} \omega 7 c$ & ND & 2.0 & 21.3 & 3.6 & 15.1 & 4.0 \\
\hline 15.91 & $\mathrm{C}_{16: 1} \omega 5 c$ & ND & ND & 6.2 & ND & 3.6 & ND \\
\hline 16 & $\mathrm{C}_{16: 0}$ & 3.9 & 5.8 & 10.2 & 15.7 & 9.6 & 10.1 \\
\hline 16.29 & $\mathrm{C}_{16: 1} \omega 7 c$ DMA & 0.2 & 0.7 & 4.2 & 1.1 & 4.6 & ND \\
\hline 16.42 & iso- $\mathrm{C}_{17: 1} \omega 10 c$ & 28.9 & 22.7 & 4.6 & 5.0 & 4.8 & 7.2 \\
\hline 16.48 & $\mathrm{C}_{16: 0} \mathrm{DMA}$ & $\mathrm{ND}$ & 1.7 & 1.8 & 3.9 & 6.7 & 5.0 \\
\hline 16.63 & iso- $\mathrm{C}_{17: 0}$ & 9.4 & 5.7 & 0.7 & 8.9 & ND & 2.4 \\
\hline 16.72 & anteiso- $\mathrm{C}_{17: 0}$ & 0.2 & $\mathrm{ND}$ & $\mathrm{ND}$ & ND & $\mathrm{ND}$ & ND \\
\hline 16.79 & $\mathrm{C}_{17: 1} \omega 8 c$ & 0.3 & ND & 1.0 & ND & $\mathrm{ND}$ & ND \\
\hline 16.86 & $\mathrm{C}_{17: 1} \omega 6 c$ & ND & ND & 1.9 & ND & $\mathrm{ND}$ & ND \\
\hline 16.88 & $\mathrm{C}_{17: 0} \mathrm{c}$ & 5.3 & 9.9 & ND & 5.8 & 2.7 & 3.7 \\
\hline 17 & $\mathrm{C}_{17: 0}$ & ND & $\mathrm{ND}$ & 0.5 & 1.4 & $\mathrm{ND}$ & ND \\
\hline 17.11 & iso- $\mathrm{C}_{17: 0}$ DMA & 0.9 & 1.1 & ND & 7.5 & $\mathrm{ND}$ & ND \\
\hline 17.47 & $\mathrm{C}_{17: 0} \mathrm{DMA}$ & ND & ND & 1.7 & ND & ND & ND \\
\hline 17.72 & $\mathrm{C}_{18: 2} \omega 6,9 c$ & 0.2 & 0.6 & ND & ND & ND & ND \\
\hline 17.77 & $\mathrm{C}_{18: 1} \omega 9 c$ & 1.0 & 2.2 & 3.4 & ND & 2.0 & ND \\
\hline 17.82 & $\mathrm{C}_{18: 1} \omega 7 c$ & 0.2 & $\mathrm{ND}$ & 6.9 & 0.9 & 3.3 & ND \\
\hline 17.92 & $\mathrm{C}_{18: 1} \omega 5 c$ & ND & ND & 2.5 & ND & 2.8 & ND \\
\hline 18 & $\mathrm{C}_{18: 0}$ & 0.4 & 2.6 & 4.4 & 3.2 & 5.6 & ND \\
\hline \multirow[t]{2}{*}{18.29} & $\mathrm{C}_{18: 1} \omega 7 c \mathrm{DMA}$ & ND & $\mathrm{ND}$ & 1.4 & ND & 1.5 & $\mathrm{ND}$ \\
\hline & Total unidentified & 4.2 & 4.4 & 1.7 & 8.5 & 19.2 & 13.0 \\
\hline
\end{tabular}

as electron donors in the presence of sulfate. Fermentative growth occurs on pyruvate. The cell wall contains mesodiaminopimelic acid. The major isoprenoid quinone is MK-7. The major whole-cell fatty acids are iso- $\mathrm{C}_{15: 0}$, iso$\mathrm{C}_{17: 0} \omega 10 c$ and iso- $\mathrm{C}_{17: 0}$. The DNA $\mathrm{G}+\mathrm{C}$ content is $48 \mathrm{~mol} \%$.

The type strain, RE35E1 ${ }^{\mathrm{T}}\left(=\mathrm{DSM} 16058^{\mathrm{T}}=\mathrm{JCM} 14019^{\mathrm{T}}\right.$ ), was isolated from a sulfidogenic FBR treating acidic metaland sulfate-containing wastewater. 


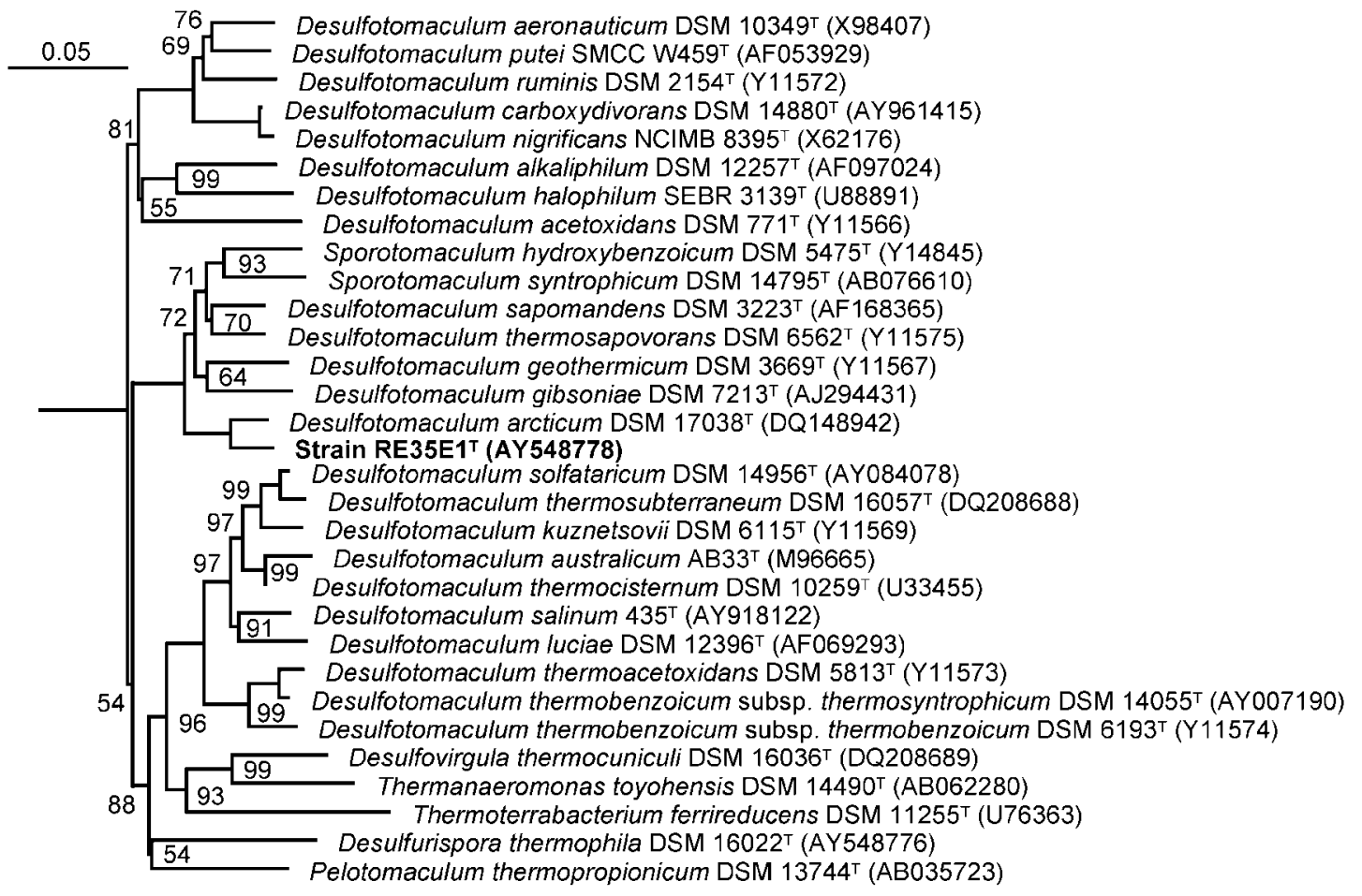

Fig. 2. Phylogenetic tree, generated using distance-matrix and neighbour-joining methods, based on 16S rRNA gene sequences of strain RE35E1 $1^{\top}$ (1429 bp between Escherichia coli positions 28 and 1459) and related taxa. Desulfitobacterium dehalogenans DSM $9161^{\top}$ (L28946) was used as outgroup (not shown). Numbers at nodes represent bootstrap percentages (based on 1000 samplings). Bar, 0.05 nucleotide changes per nucleotide.

\section{Acknowledgements}

This work was supported by the Finnish Funding Agency for Technology and Innovation, Outokumpu Oyj, Finland, the Finnish Graduate School in Environmental Science and Technology, Academy of Finland and the European Commission (BioMinE contract 500329 and a grant for the DSMZ large-scale facility). Annukka Hämäläinen, Esther Schüler, Anika Vester and Marlen Jando are acknowledged for their technical assistance.

\section{References}

Altschul, S. F., Gish, W., Miller, W., Myers, E. W. \& Lipman, D. J. (1990). A basic local alignment search tool. J Mol Biol 215, 403-410.

Campbell, L. L. \& Postgate, J. R. (1965). Classification of the sporeforming sulfate-reducing bacteria. Bacteriol Rev 29, 359-363.

Cashion, P., Holder-Franklin, M. A., McCully, J. \& Franklin, M. (1977). A rapid method for base ratio determination of bacterial DNA. Anal Biochem 81, 461-466.

Collins, M. D. \& Jones, D. (1981). Distribution of isoprenoid quinone structural types in bacteria and their taxonomic implications. Microbiol Rev 45, 316-354.

Cord-Ruwisch, R. \& Garcia, J.-L. (1985). Isolation and characterization of an anaerobic benzoate-degrading spore-forming sulfatereducing bacterium Desulfotomaculum sapomandens sp. nov. FEMS Microbiol Lett 29, 325-330.

Daumas, S., Cord-Ruwisch, R. \& Garcia, J. L. (1988). Desulfotomaculum geothermicum sp. nov., a thermophilic, fatty acid-degrading, sulfate-reducing bacterium isolated with $\mathrm{H}_{2}$ from geothermal ground water. Antonie Van Leeuwenhoek 54, 165-178.

Fardeau, M.-L., Ollivier, B., Patel, B. K. C., Dwivedi, P., Ragot, M. \& Garcia, J.-L. (1995). Isolation and characterization of a thermophilic sulfate-reducing bacterium, Desulfotomaculum thermosapovorans sp. nov. Int J Syst Bacteriol 45, 218-221.

Goorissen, H. P., Boschker, H. T. S., Stams, A. J. M. \& Hansen, T. A. (2003). Isolation of thermophilic Desulfotomaculum strains with methanol and sulfite from solfataric mud pools, and characterization of Desulfotomaculum solfataricum sp. nov. Int J Syst Evol Microbiol 53, 1223-1229.

Gregersen, T. (1978). Rapid method for distinction of Gram-negative from Gram-positive bacteria. Eur J Appl Microbiol Biotechnol 5, 123-127.

Groth, I., Schumann, P., Weiss, N., Martin, K. \& Rainey, F. A. (1996). Agrococcus jenesis gen. nov., sp. nov., a new genus of actinomycetes with diaminobutyric acid in the cell wall. Int J Syst Bacteriol 46, 234-239.

Hagenauer, A., Hippe, H. \& Rainey, F. A. (1997). Desulfotomaculum aeronauticum sp. nov., a sporeforming, thiosulfate-reducing bacterium from corroded aluminium alloy in an aircraft. Syst Appl Microbiol 20, 65-71.

Heimbrook, M. E., Wang, W. L. L. \& Campbell, G. (1989). Staining bacterial flagella easily. J Clin Microbiol 27, 2612-2615.

Kaksonen, A. H., Franzmann, P. D. \& Puhakka, J. A. (2003a). Performance and ethanol oxidation kinetics of a sulfate-reducing fluidized-bed reactor treating acidic metal-containing wastewater. Biodegradation 14, 207-217. 
Kaksonen, A. H., Riekkola-Vanhanen, M.-L. \& Puhakka, J. A. (2003b). Optimization of metal sulfide precipitation in fluidized-bed treatment of acidic wastewater. Water Res 37, 255-266.

Kaksonen, A. H., Franzmann, P. D. \& Puhakka, J. A. (2004a). Effects of hydraulic retention time and sulfide toxicity on ethanol and acetate oxidation in sulfate-reducing metal-precipitating fluidized-bed reactor. Biotechnol Bioeng 86, 332-343.

Kaksonen, A. H., Plumb, J. J., Gibson, J. A. E., Franzmann, P. D. \& Puhakka, J. A. (2004b). Simple organic electron donors support diverse sulfate-reducing communities in fluidized-bed reactors treating acidic metal- and sulfate-containing wastewater. FEMS Microbiol Ecol 47, 279-289.

Kaksonen, A. H., Plumb, J. J., Robertson, W. J., Franzmann, P. D., Gibson, J. A. E. \& Puhakka, J. A. (2004c). Culturable diversity and community fatty acid profiling of sulfate-reducing fluidized-bed reactors treating acidic, metal-containing wastewater. Geomicrobiol J 21, 1-12.

Kaksonen, A. H., Plumb, J. J., Robertson, W. J., Spring, S., Schumann, P., Franzmann, P. D. \& Puhakka, J. A. (2006a). Novel thermophilic sulfate-reducing bacteria from a geothermally active underground mine in Japan. Appl Environ Microbiol 72, 3759-3762.

Kaksonen, A. H., Spring, S., Schumann, P., Kroppenstedt, R. M. \& Puhakka, J. A. (2006b). Desulfotomaculum thermosubterraneum sp. nov., a thermophilic sulfate-reducer isolated from an underground mine located in geothermally active area. Int J Syst Evol Microbiol 56, 2603-2608.

Kämpfer, P. \& Kroppenstedt, R. M. (1996). Numerical analysis of fatty acid patterns of coryneform bacteria and related taxa. Can J Microbiol 42, 989-1005.

Kroppenstedt, R. M. (1985). Fatty acid and menaquinone analysis of actinomycetes and related organisms. In Chemical Methods in Bacterial Systematics (Society for Applied Bacteriology Technical Series, vol. 20), pp. 173-199. Edited by M. Goodfellow \& D. E. Minnikin. New York: Academic Press.

Kuever, J., Rainey, F. A. \& Hippe, H. (1999). Description of Desulfotomaculum sp. Groll as Desulfotomaculum gibsoniae sp. nov. Int J Syst Bacteriol 49, 1801-1808.

Liu, Y., Karnauchow, T. M., Jarrell, K. F., Balkwill, D. L., Drake, G. R., Ringelberg, D., Clarno, R. \& Boone, D. R. (1997). Description of two new thermophilic Desulfotomaculum spp., Desulfotomaculum putei sp. nov., from a deep terrestrial subsurface, and Desulfotomaculum luciae sp. nov., from a hot spring. Int J Syst Bacteriol 47, 615-621.

Love, C. A., Patel, B. K. C., Nichols, P. D. \& Stackebrandt, E. (1993). Desulfotomaculum australicum, sp. nov., a thermophilic sulfatereducing bacterium isolated from the Great Artesian Basin of Australia. Syst Appl Microbiol 16, 244-251.

Lovley, D. R. \& Phillips, E. J. P. (1986). Organic matter mineralization with reduction of ferric iron in anaerobic sediments. Appl Environ Microbiol 51, 683-689.

Mesbah, M., Premachandran, U. \& Whitman, W. B. (1989). Precise measurement of the $\mathrm{G}+\mathrm{C}$ content of deoxyribonucleic acid by highperformance liquid chromatography. Int J Syst Bacteriol 39, 159-167.

Miller, L. T. (1982). Single derivatization method for routine analysis of bacterial whole-cell fatty acid methyl esters, including hydroxy acids. J Clin Microbiol 16, 584-586.

Min, H. \& Zinder, S. H. (1990). Isolation and characterization of a thermophilic sulfate-reducing bacterium, Desulfotomaculum thermoacetoxidans sp. nov. Arch Microbiol 153, 399-404.
Monciardini, P., Cavaletti, L., Schumann, P., Rohde, M. \& Donadio, S. (2003). Conexibacter woesei gen. nov., sp. nov., a novel representative of a deep evolutionary line of descent within the class Actinobacteria. Int J Syst Evol Microbiol 53, 569-576.

Nazina, T. N., Ivanova, A. E., Kanchaveli, L. P. \& Rozanova, E. P. (1989). A new sporeforming thermophilic methylotrophic sulfatereducing bacterium, Desulfotomaculum kuznetsovii sp. nov. Microbiology (English translation of Mikrobiologiia) 57, 659-663.

Nazina, T. N., Rozanova, E. P., Belyakova, E. V., Lysenko, A. M., Poltaraus, A. B., Tourova, T. P., Osipov, G. A. \& Belyaev, S. S. (2005). Description of 'Desulfotomaculum nigrificans subs. salinus' as a new species, Desulfotomaculum salinum sp. nov. Microbiology (English translation of Mikrobiologiia) 74, 567-574.

Nilsen, R. K., Torsvik, T. \& Lien, T. (1996). Desulfotomaculum thermocisternum sp. nov., a sulfate-reducer isolated from a hot North Sea oil reservoir. Int J Syst Bacteriol 46, 397-402.

Parshina, S. N., Sipma, J., Nakashimada, Y., Meint Henstra, A., Smidt, H., Lysenko, A. M., Lens, P. N. L., Lettinga, G. \& Stams, A. J. M. (2005). Desulfotomaculum carboxydivorans sp. nov., a novel sulfatereducing bacterium capable of growth at $100 \%$ CO. Int J Syst Evol Microbiol 55, 2159-2165.

Pikuta, E., Lysenko, A., Suzina, N., Osipov, G., Kuznetsov, B., Tourova, T., Akimenko, V. \& Laurinavichius, K. (2000). Desulfotomaculum alkaliphilum sp. nov., a new alkaliphilic, moderately thermophilic, sulfate-reducing bacterium. Int J Syst Evol Microbiol 50, 25-33.

Plugge, C. M., Balk, M. \& Stams, A. J. M. (2002). Desulfotomaculum thermobenzoicum subsp. thermosyntrophicum subsp. nov., a thermophilic, syntrophic, propionate-oxiding, spore-forming bacterium. Int J Syst Evol Microbiol 52, 391-399.

Rhuland, L. E., Work, E., Denman, R. F. \& Hoare, D. S. (1955). The behavior of the isomers of $\alpha, \varepsilon$-diaminopimelic acid on paper chromatograms. J Am Chem Soc 77, 4844-4846.

Sasser, M. (1990). Identification of bacteria by gas chromatography of cellular fatty acids. USFCC Newsl 20, 16.

Tamaoka, J. \& Komagata, K. (1984). Determination of DNA base composition by reversed-phase high-performance liquid chromatography. FEMS Microbiol Lett 25, 125-128.

Tardy-Jacquenod, C., Magot, M., Patel, B. K., Matheron, R. \& Caumette, P. (1998). Desulfotomaculum halophilum sp. nov., a halophilic sulfate-reducing bacterium isolated from oil production facilities. Int J Syst Bacteriol 48, 333-338.

Tasaki, M., Kamagata, Y., Nakamura, K. \& Mikami, E. (1991). Isolation and characterization of a thermophilic benzoate-degrading, sulfate-reducing bacterium, Desulfotomaculum thermobenzoicum sp. nov. Arch Microbiol 155, 348-352.

Vandieken, V., Knoblauch, C. \& Jorgensen, B. B. (2006). Desulfotomaculum arcticum sp. nov., a new spore-forming, moderately thermophilic sulfate-reducing bacterium isolated from a permanently cold fjord sediment of Svalbard. Int J Syst Evol Microbiol 56, 687-690.

Werkman, C. H. \& Weaver, H. J. (1927). Studies in the bacteriology of sulphur stinker spoilage of canned sweet corn. Iowa State Coll J Sci 2, 57-67.

Widdel, F. \& Pfennig, N. (1977). A new anaerobic, sporing, acetateoxidizing, sulfate-reducing bacterium, Desulfotomaculum (emend.) acetoxidans. Arch Microbiol 112, 119-122. 